\title{
Gradient of Extrajunctional Acetylcholine Receptors Early After Denervation of Mammalian Muscle
}

\author{
Tami A. Levitt-Gilmour and Miriam M. Salpeter \\ Section of Neurobiology and Behavior, Cornell University, Ithaca, New York 14853
}

\begin{abstract}
After denervation, the number of acetylcholine receptors (AChR) found within the endplate band of skeletal muscle increases transiently by about twofold. In this study, we used EM autoradiography to show that this increased endplate band label is not due to an elevated site density of receptors at the junctional folds. Rather, AChR site density within $500 \mu \mathrm{m}$ of the endplate was found to be $4 \times$ higher than in non-endplate areas defined as greater than $2 \mathrm{~mm}$ from the endplate. This nonuniform distribution of extrajunctional $\mathrm{AChR}$ early after denervation could represent a transient gradient, similar to that reported shortly after innervation during development.
\end{abstract}

The distribution of acetylcholine receptors (AChRs) on muscle is controlled by the nerve in a complex manner. AChRs on adult muscle are restricted to the neuromuscular junction (NMJ), where they are highly concentrated at the tops of the junctional folds (about 15,000-20,000 AChR binding sites $/ \mu \mathrm{m}^{2}$ ) (Fertuck and Salpeter, 1974, 1976; Land et al., 1980; Matthews-Bellinger and Salpeter, 1978; Porter and Barnard, 1975). When the nerve is cut, receptor synthesis is stimulated (see review by Fambrough, 1979) and by $8 \mathrm{~d}$ after the nerve is cut, extrajunctional receptors appear all over the muscle surface with a low site density (about 200-400 sites $/ \mu \mathrm{m}^{2}$ ) (Chang et al., 1975; Fambrough, 1974; Loring and Salpeter, 1978; Pestronk et al., 1976a, b). However, the density of junctional AChR has been reported to remain unchanged at the denervated NMJ at least for a few weeks (Bader, 1981; Loring and Salpeter, 1980; Porter and Barnard, 1975); and to decrease slowly thereafter (Frank et al., 1975; Steinbach, 1981b).

Not only is the rate of AChR synthesis affected by the nerve, the degradation rate of $\mathrm{AChR}$ also depends on the state of muscle innervation. The half-life of extrajunctional receptors either prior to innervation or after denervation is about $1 \mathrm{~d}$, which is about $8-10 \times$ shorter than that of AChRs found at an innervated NMJ. After denervation the degradation rate of junctional receptors accelerates (see review by Salpeter and Loring, 1985). The mechanism by which the site density of junctional receptors remains constant early after denervation, despite the changing rates of synthesis and degradation, is an interesting yet unanswered question.

Before this question can be answered, it is important to establish that the AChR site density does in fact remain constant during this period. Recently, Olek and Robbins (1981) challenged this assertion. They reported that the number of receptors increased dramatically on the end plate band of strips of cultured diaphragm muscle between 40 and $46 \mathrm{hr}$ after denervation. The

\footnotetext{
Received May 20, 1985; revised Nov. 12, 1985; accepted Nov. 15, 1985.

We thank Dorothy P. Bell and Rose Harris for technical assistance and Patricia Curran for typing the manuscript. This work was supported by NIH Grant NS 09315.

Correspondence should be addressed to Miriam M. Salpeter, Section of Neurobiology and Behavior, W113 Mudd Hall, Cornell University, Ithaca, NY 14853. Copyright (C) 1986 Society for Neuroscience $0270-6474 / 86 / 061606-07 \$ 02.00 / 0$
}

new receptors were localized to within $150 \mu \mathrm{m}$ of the junction and were considered to be, at least in part, junctional (Olek and Robbins, 1983; Olek et al., 1981). However, these studies used gamma counting to determine the endplate specific label, and that technique cannot resolve whether the new AChRs represent an increase in the site density of junctional receptors (i.e., located at the junctional folds of the NMJ), or of extrajunctional receptors added in the vicinity of the endplate.

We therefore used both gamma counting and high-resolution EM autoradiography to reevaluate the receptor site density both in junctional and extrajunctional regions at early times after denervation in vivo. We found no increase in junctional AChR. We found, however, a marked increase in extrajunctional receptors located selectively near the NMJ. The nonuniform distribution of extrajunctional receptors early after denervation is sufficient to account for the increased number of receptors in the endplate band.

\section{Materials and Methods}

\section{Purification and iodination of $\alpha$-bungarotoxin (BGT)}

Crude toxin was purified using a modification of the method of Lee et al. (1972). BGT was iodinated using the lactoperoxidase method of Morrison and Bayse (1970) using carrier-free iodine ${ }^{125}$ I obtained from Amersham. It was then purified on a G-25 column. The specific activity was determined and the integrity of the toxin verified using the methods described by Loring et al. (1982). In these experiments, several batches of toxin were used, ranging in specific activity from 131 to $518 \mathrm{Ci}$ / mmol at the time of iodination.

\section{Denervation of sternomastoid muscle}

Female albino mice (25-34 gm) were operated under Nembutal anesthesia. The sternomastoid muscle was denervated by removing a $1 \mathrm{~mm}$ piece of nerve, close to where the nerve enters the muscle.

\section{Determination of "endplate band specific" label by gamma counting \\ BGT was used to label AChR (Lee et al., 1972). Animals were injected with nonlethal doses of ${ }^{125}$ I-BGT $(4.1 \mu \mathrm{g} / 100 \mathrm{gm}$ body weight, i.p.) at various times after denervation. (This does not saturate all receptors.) Four hours later, the animals were killed by intracardial perfusion with $4 \%$ paraformaldehyde in $0.05 \mathrm{~m}$ phosphate buffer ( $\mathrm{pH} 7.4$ ) (Karnovsky, 1965). Both the innervated and denervated sternomastoid muscles were removed, washed several times in $0.05 \mathrm{M}$ Na phosphate buffer and stained for AChE (Karnovsky and Roots, 1964) to identify the endplate band. Each muscle was cut into 3 pieces, with 1 containing the endplate band. Each piece was then weighed and counted in a gamma counter. Non-endplate band label was calculated per gram of tissue by pooling the counts in the 2 pieces not containing endplates and dividing by their total weight. "Endplate band specific" label was then calculated by subtracting the non-endplate band label from the endplate label on a per weight basis. This subtraction procedure assumes a uniform distri- bution of extrajunctional label. Since the endplate receptors were not saturated by the injection, the data obtained can only be used to compare the denervated to the innervated muscle, not to get absolute binding site values.}




\section{EM autoradiography}

\section{Fixation and saturation of tissue with ${ }^{125} I-B G T$}

In order to obtain the total receptor site density, the muscles were saturated with ${ }^{125}$ I-BGT in vitro after prefixation with the metaperiodate-lysine-paraformaldehyde fixative of McLean and Nakane (1974) as calibrated by Matthews-Bellinger and Salpeter (1983). This fixation still allows BGT to bind to AChR as in fresh tissue, although there is a slightly heavier background in prefixed than in fresh tissue even after extensive washes as described below. The heavier backgrounds decrease the accuracy of the determination of endplate band specific label by gamma counting, but is insignificant for EM autoradiography, where background can be easily subtracted (see below). The following procedure was followed: Four days after denervation, mice were anesthetized with Nembutal $(7 \mathrm{mg} / 100 \mathrm{gm}$ body weight, i.p.) and killed by intracardial perfusion with fresh metaperiodate-lysine-paraformaldehyde fixative (McLean and Nakane, 1974) - 2\% paraformaldehyde in $0.1 \mathrm{M}$ $\mathrm{NaIO}_{4}$ and $0.075 \mathrm{M}$ lysine-hydrochloride in $0.037 \mathrm{M}$ Na phosphate buffer, pH 7.4. The sternomastoid muscles were removed and immersed in the same fixative for an additional $3 \mathrm{hr}$ at $4^{\circ} \mathrm{C}$, followed by 3 half-hour rinses in $0.05 \mathrm{M} \mathrm{Na}$ phosphate buffer, $\mathrm{pH} 7.4$, with $6.84 \mathrm{gm}$ sucrose. The muscles were then washed in phosphate buffer overnight at $4^{\circ} \mathrm{C}$ to remove excess fixative. The next morning, the muscles were exposed to $0.6 \mu \mathrm{M}{ }^{125} \mathrm{I}-\mathrm{BGT}$ for $2 \mathrm{hr}$ at room temperature. The overnight wash after fixation was essential in order to minimize nonspecific binding in these prefixed tissues, as were several extensive washes after labeling: first, several times in buffer containing $1 \mathrm{mg} / \mathrm{ml} \mathrm{BSA}$ for $30 \mathrm{~min}$, then in BSA-buffer solution containing 3.0 $\mu \mathrm{m}$ unlabeled BGT. Each muscle was then cut into 3 pieces, 1 containing the endplate band, washed in BSA-buffer overnight at $4^{\circ} \mathrm{C}$, and then prepared for EM autoradiography as described below. Such autoradiograms gave information on site densities for total AChR (i.e., residual receptors present prior to denervation and any newly inserted after denervation).

\section{Determination of only new receptors inserted after denervation}

To localize only receptors newly inserted during the $4 \mathrm{~d}$ after denervation, original receptors (i.e., receptors already inserted at the NMJ prior to denervation) of two animals were inactivated in vivo (Fertuck et al., 1975) with nonradioactive BGT prior to denervating the muscles. To do this, the head of the mouse was tilted and a small incision was made in the neck. The salivary glands and connective tissue were moved aside and the skin pulled back so that the skin and surrounding tissues made a small cavity in which the sternomastoid muscle was exposed. The muscle was bathed topically in BGT $(3.0 \mu \mathrm{M})$ for $3 \mathrm{hr}$. A suction electrode on the nerve was used to stimulate the muscle indirectly in order to verify that the time required to abolish all tetanic muscle twitching is about $1.5 \mathrm{hr}$, as previously reported (Fertuck et al., 1975) and, thus, half the total incubation time used. (Control experiments show that all but $1 \%$ of the original receptors are inactivated during the $3 \mathrm{hr}$ in vivo incubation.) Four days later, the animals were killed by perfusion with metaperiodate-lysine-paraformaldehyde fixative (McLean and Nakane, 1974), and the new receptors of the denervated muscle saturated with ${ }^{125}$ I-BGT in vitro (as described above) and processed for EM autoradiography.

\section{Preparation of autoradiograms}

The aldehyde-fixed tissue both from the endplate and non-endplate band region was cut into small pieces and postfixed in $1 \%$ osmium in $0.05 \mathrm{M}$ phosphate buffer for $1 \mathrm{hr}$, rinsed, and stained in $2 \%$ aqueous uranyl acetate for an additional hour. The tissue was washed and dehydrated in graded concentrations of ethyl alcohol, followed by propylene oxide, and embedded in Epon 812. Autoradiograms were prepared using the flat substrate method of Salpeter and Bachmann (1964). For technical details see Salpeter (1981). Tissue sections on collodioncoated slides were coated with Ilford L4 emulsion and developed with $\mathrm{D} 19,20^{\circ} \mathrm{C}$ for $2 \mathrm{~min}$. Only autoradiographs with distinct, sharp images of postjunctional membrane were used for analysis (Fig. 1).

\section{Determination of site densities}

Receptor site densities for innervated and denervated endplates and extrajunctional regions were determined as previously described (Fertuck and Salpeter, 1976; Loring and Salpeter, 1980; Matthews-Bellinger and Salpeter, 1978). For junctional receptor site density, all grains lying within $0.5 \mu \mathrm{m}$ on the axonal side and $1.0 \mu \mathrm{m}$ on the muscle side were tabulated, thus including receptors throughout the junctional folds, either due to radiation spread from the dense membrane receptive surface or locally generated. These were then related to the surface area of the endplate or to the surface area of the dense "receptor-rich" postjunctional membrane as follows.

The surface area of the endplate was obtained by measuring a "primary cleft line" and multiplying it by the thickness of the section (measured by interferometry prior to emulsion coating). For innervated profiles the primary cleft line was the axon membrane apposed to the junctional folds. For denervated profiles, the primary cleft line was a line drawn across the tops of the junctional folds. The surface area of the dense postjunctional membrane (i.e., receptive surface area) was measured in the autoradiograms of the denervated and innervated profiles, and then multiplied by the section thickness. Membrane or line measurements were made using a bitpad interfaced to a PDP-11 computer.

Background values were obtained by counting grains in a random 6 $\mu \mathrm{m}^{2}$ area of the muscle on every picture. The background grains per unit area were multiplied by the area of autoradiogram tabulated, and subtracted from the total counts over the endplates. Denervated muscle has cytoplasmic label (Loring and Salpeter, 1978). Yet because of the small area of endplate and high junctional receptor density, the background was negligible ( $<0.5 \%$ of total) in determining junctional site densities. The AChR sites per square micron of either primary cleft or dense postjunctional membrane were then calculated from the grains/ $\mu \mathrm{m}^{2}$ using the formula given by Fertuck and Salpeter (1976).

To tabulate extrajunctional site densities, all grains within $0.24 \mu \mathrm{m}$ of the plasma membrane were counted-i.e., 3 resolution half-distances (HDs) for I-125 (Salpeter et al., 1977) and expected to contain about $87 \%$ of total grains due to label on the membrane. In order to avoid problems due to radiation spread, only fibers that were farther than 0.5 $\mu \mathrm{m}$ (6 HD) (Salpeter et al., 1977) from other fibers were counted. The length of membrane was again determined using the PDP-11 computer interfaced to a bitpad and multiplied by the section thickness to obtain the membrane area. The background was subtracted from the total grains as for junctional areas. For the long exposures required and the relatively low extrajunctional site densities, background became more significant: with between 6 and $12 \%$ of the total grains counted from the extrajunctional membrane subtracted as background. The grains per square micron of extrajunctional surface area were then calculated. Since $0.24 \mu \mathrm{m}$ contains only $87 \%$ of the total grains associated with the membrane (Salpeter et al., 1977), the grain density was multiplied by 1.15 . The site density was then calculated as for junctional receptors.

For all site densities, error ranges were given by $1 / \sqrt{N}$, where $N$ is the number of grains analyzed per condition (Salpeter and Bachmann, 1972).

\section{Size of endplates}

Two animals, whose right sternomastoid was denervated for $4 \mathrm{~d}$, were killed, their endplates stained for AChE (Karnovsky and Roots, 1964), and both the denervated and innervated muscles bathed in $4 \mathrm{M} \mathrm{HCl}$ (Evans et al., 1976) until the fibers began to separate (about $1 \mathrm{~min}$ ). Restaining the separated fibers for AChE gave clear images of the endplates. The sizes of the endplates of the separated fibers were then measured using a calibrated grid in the ocular of a light microscope. In addition, the ratio of total junctional fold membrane to primary cleft line was determined as previously described (Salpeter et al., 1972).

\section{Results}

\section{Time-dependent increases in endplate specific receptor number after denervation}

At different times after denervation of the right sternomastoid muscle, the endplate band specific label was determined by gamma counting as described in Materials and Methods. Figure 2 shows the ratio of denervated to innervated label. Our result is similar to that described by Olek et al. (1981) in diaphragm muscle: the number of endplate band specific counts increase about 2-fold by 2-4 d after denervation and decreased again by 6-8 d after denervation. Since the increase peaked at about $4 \mathrm{~d}$ after denervation, we chose this time to see if the transient population of postdenervation receptors is localized at the neu- 

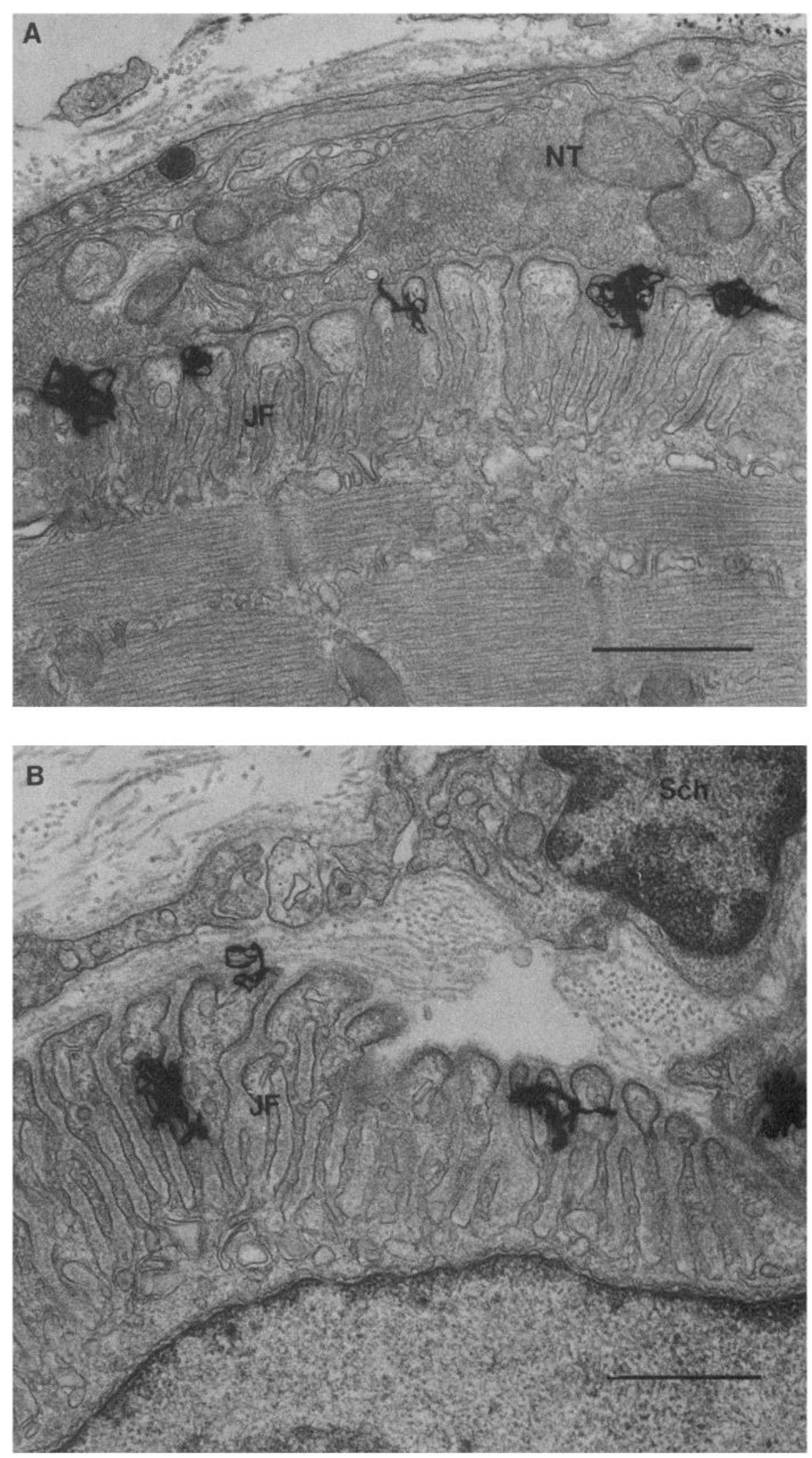

Figure 1. Sample EM autoradiographs of innervated $(A)$ and denervated $(B)$ muscles used for analysis of junctional AChRs. NT, Nerve terminal; $J F$, junctional folds; $S c h$, Schwann cell. Scale bar, $1 \mu \mathrm{m}$. 


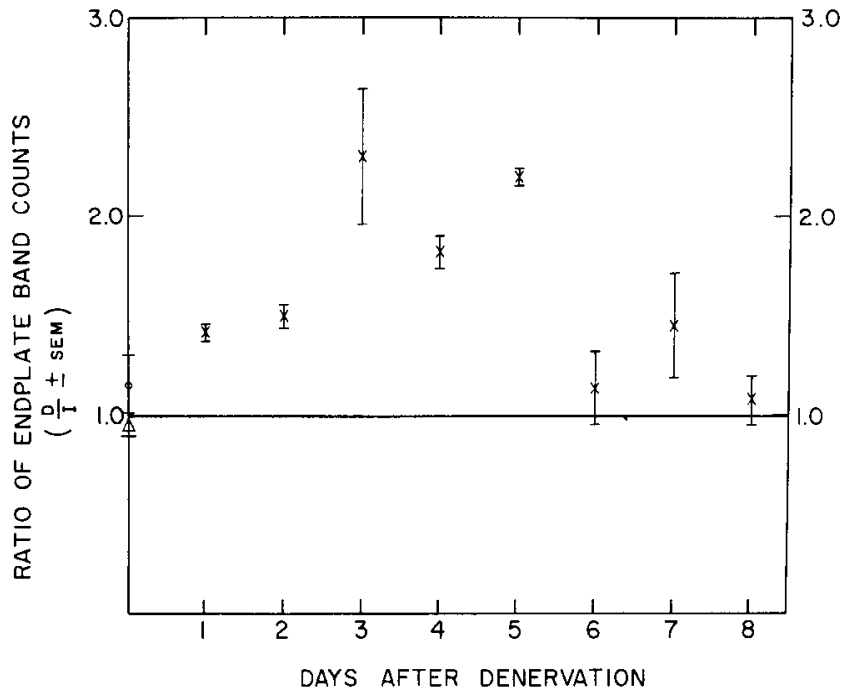

Figure 2. Endplate band label doubles at early times after denervation. Endplate band specific label was determined by subtracting non-endplate counts on a per weight basis, and the ratio of label on the denervated (D) to innervated (I) side plotted versus time. Open triangle shows ratio of right to left side in fully innervated control animals, killed $4 \mathrm{hr}$ after injection.

romuscular junction (defined as being on the junctional folds), or in extrajunctional regions within the endplate band.

\section{Morphology}

Figure 1 shows a $4 \mathrm{~d}$ denervated and innervated junction. This figure illustrates a typical cross section used for analysis. It also illustrates the relatively unchanged junctional fold topography at the time of this study. The measured ratio of primary cleft linc to that of the total junctional folds was $1 / 4.9 \pm 0.3$ for innervated and $1 / 5.0 \pm 0.2$ for denervated junctions. These were the same as at later stages ( $8 \mathrm{~d}$ ) after denervation (Loring and Salpeter, unpublished observations; Porter and Barnard, 1975). The edges of the AChE-stained endplates appeared somewhat more diffuse in the denervated endplates. However, the overall sizes of the endplates also did not change significantly and were $57 \pm 2 \times 34 \pm 2 \mu \mathrm{m}$ for both the innervated and the $4 \mathrm{~d}$ denervated junctions. This again is consistent with findings in other species that endplate size does not increase early after denervation (Labovitz et al., 1984; Steinbach, 1981b). The overall appearance of the endplate contours judged subjectively was also unchanged at this time.

\section{Junctional receptors}

If the increase in endplate-specific label is due to an increase in site density of junctional receptors, there must be a massive increase in newly inserted junctional receptors during the $4 \mathrm{~d}$ denervation period. We therefore used EM autoradiography to determine the site density of both the total junctional receptor population and of the newly inserted receptors by protocols described in Materials and Methods. Figure $3 A$ shows that there is no difference in the site density of total junctional receptors in the innervated and denervated muscles of 2 animals $4 \mathrm{~d}$ after denervation, either when the grains were related to primary cleft surface area (i.e., surface area of total junction) or when they were related to the dense specialized receptive membrane at the top of the junctional folds as previously established for $>90 \%$ of the sites on innervated junctions (Fertuck and Salpeter, 1976; Salpeter and Harris, 1983; Salpeter et al., 1984). All muscles had AChR (BGT binding) site densities of about 25,600 sites $/ \mu \mathrm{m}^{2}$ surface area of primary cleft or $16,000 \mathrm{sites} / \mu \mathrm{m}^{2}$ re-

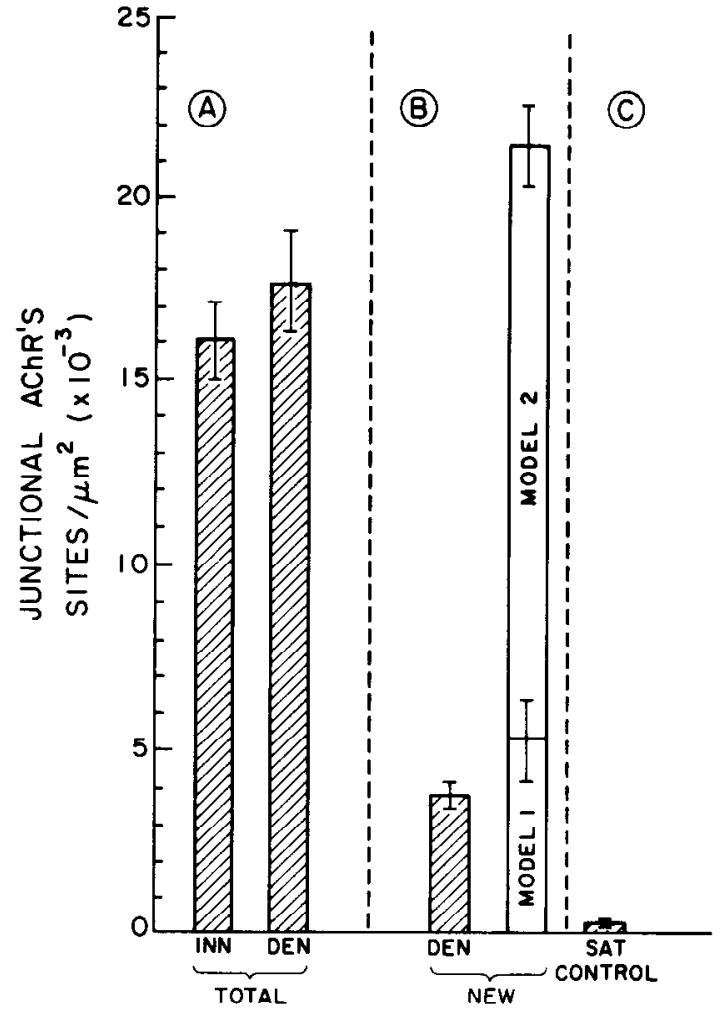

Figure 3. A, Total junctional receptors: BGT binding site density of total junctional receptors at $4 \mathrm{~d}$ denervated endplates, determined by EM autoradiography (see Materials and Methods). The right sternomastoid muscle was denervated. Four days later the innervated (INN) and denervated $(D E N)$ muscles were removed and saturated with ${ }^{125}$ I$\alpha$-BGT (see Materials and Methods). B, Junctional receptors newly inserted during $4 \mathrm{~d}$ after denervation: Original receptors (i.e., receptors present at junction prior to denervation) were presaturated with unlabeled BGT in vivo (see Materials and Methods) just before the right sternomastoid muscle was denervated. Four days later the muscle was removed and newly inserted receptors $(D E N)$ saturated with ${ }^{125}$ I-BGT. Model 1 shows the expected number of newly inserted junctional receptors necessary to replace original junctional receptors as they decay with an $8 \mathrm{~d}$ half-life over the $4 \mathrm{~d}$ denervation period (Levitt and Salpeter, 1981). Model 2 shows the expected number of newly inserted junctional receptors if the twofold increase seen in endplate-band-specific label is due to an increase in junctional receptor site density. $C$, Saturation control (Sat control), performed by saturating all receptors with nonradioactive $\mathrm{BGT}$ in vivo followed immediately by ${ }^{125}$ I-BGT in vitro, shows that all but $1 \%$ of $A C h R s$ were saturated by the presaturation protocol.

lated to dense postjunctional membrane (Fig. $3 A$ ), and thus equal to that previously reported in different vertebrate muscles (Bader, 1981; Land et al., 1980; Loring and Salpeter, 1980; Matthews-Bellinger and Salpeter, 1978; Porter and Barnard, 1975).

Figure $3 B$ shows that the site density of junctional receptors newly inserted during the $4 \mathrm{~d}$ period after denervation is not different from that expected (model 1 ) due to a replacement of the "original" receptors, as they degrade with a half-life of $8 \mathrm{~d}$ (Levitt and Salpeter, 1981). If the junctional site density had doubled early after denervation then one would expect, in addition to the replacement of the original receptors (as in model 1), 16,000 new sites $/ \mu \mathrm{m}^{2}$ inserted over the $4 \mathrm{~d}$ period (model 2).

Our tabulation included grains over the entire area of the junctional folds, and we did not independently determine whether the normal gradient down the folds (Salpeter et al., 1984) was altered after denervation. Therefore, if there had been an in- 


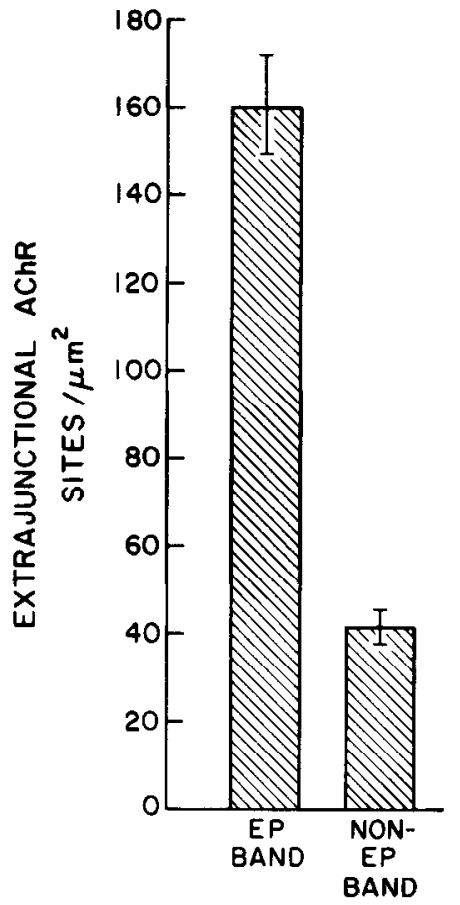

Figure 4. Site density of extrajunctional receptors within the endplate band versus that far from the endplate band (i.e., $>2 \mathrm{~mm}$ away) determined by EM autoradiography $4 \mathrm{~d}$ after denervation.

crease in the number of receptors at the bottom of the folds, we would have expressed it as an increase in the average site density. No such increase was seen. Thus, the 2-fold increase in endplate specific receptors obtained by gamma counting early after denervation cannot be due to an increase in AChR site density anywhere at the NMJ.

\section{Evidence for a nonuniform distribution of extrajunctional receptors}

To examine the possibility that the early postdenervation increase in endplate band receptors is due to the appearance of extrajunctional receptors preferentially near the junction, we used EM autoradiography and compared the site density of extrajunctional receptors in the endplate band tissue (within 500 $\mu \mathrm{m}$ of the endplate), to that in non-endplate band tissue (at least $2 \mathrm{~mm}$ away from the NMJ). We found (Fig. 4) that $4 \mathrm{~d}$ after denervation, the extrajunctional receptors within the endplate band have a binding site density of $160 \pm 14$ sites $/ \mu \mathrm{m}^{2}$, whereas those in the non-endplate band areas are about $4 \times$ less concentrated (only $42 \pm 7$ sites $/ \mu \mathrm{m}^{2}$ ).

\section{Discussion}

\section{Postdenervation junctional AChR site density}

We conclude that at $4 \mathrm{~d}$ after denervation the receptor site density at the NMJ is the same as in innervated junctions, just as previously reported for later times after denervation (Bader, 1981; Loring and Salpeter, 1980; Porter and Barnard, 1975). Furthermore, no increase in endplate size nor junctional fold length after denervation was seen to explain an increased number of junctional receptors.

Olek and Robbins (1981) have reported that the surge in $A C h R$ insertion in the endplate band between 40 and $48 \mathrm{hr}$ after denervation is dependent on the length of residual nerve stump. These data suggest that a neural factor may control the time for initiation of new postdenervation receptor synthesis. In light of our data, showing that the increased receptors are likely to be extrajunctional, we are at a loss to explain their subsequent observation that these receptors have a slow degradation rate, just as innervated junctional receptors do (Olek and Robbins, 1983). One possible explanation is that a small percentage of original receptors that were not fully inactivated by cold toxin prior to denervation (and which would constitute a sizable proportion of total receptors studied just a few hours later) were not corrected for in their calculation of the half-life of newly inserted receptors at the postdenervation endplate band. We have found no evidence of a population of new junctional AChRs with a slow degradation rate at $4 \mathrm{~d}$ postdenervation in vivo (Levitt, Lynch, and Salpeter, unpublished observations).

\section{Gradients of extrajunctional receptors and steady-state junctional AChR site density}

During development, after the nerve contacts the muscle, extrajunctional receptors, once evenly distributed over the muscle surface, decline in number. As their number declines, they remain most numerous near the endplate, forming a gradient away from the endplate (Bevan and Steinbach, 1977; Burden, 1977). Receptor gradients also exist near the junction in the adult (Hartzell and Fambrough, 1972) but arc much steeper (Fertuck and Salpeter, 1976; Kuffler and Yoshikami, 1975). Previous reports on whether extrajunctional gradients exist after denervation are contradictory (e.g., Albuquerque and McIsaac, 1970; Fambrough, 1970; Olek and Robbins, 1981; Steinbach, 1981a), and their existence may depend on the muscle used and to some extent on how soon after denervation the data are obtained. We have found that early ( 4 d) after denervation, extrajunctional receptors are nonuniformly distributed in the mouse sternomastoid muscle, being $4 \times$ more concentrated near the endplate (i.e., within $500 \mu \mathrm{m}$ ) than far from it (>2 mm away). We conclude that the extrajunctional receptors within the endplate band account for the increase detected by gamma counting early after denervation.

Changes in nuclear activity are known to occur after denervation. The most obvious is the finding that many non-endplate nuclei become enlarged, resembling the soleplate nucleus (e.g., Tower, 1939; also our observation). In addition, mRNA for the AChR alpha subunit increases considerably after denervation (Goldman et al., 1985; Merlie et al., 1984). A gradient of extrajunctional receptors might be established if, after denervation, the muscle nuclei with increasing distance from the endplate were sequentially triggered to transcribe message for $\mathrm{AChR}$, followed by local translation of proteins and local insertion into the extrajunctional muscle membrane.

An extrajunctional gradient could also be established if the junctional AChR site density is maintained, as, for instance, by anchoring sites (e.g., Salpeter and Harris, 1983) that would determine an upper limit to the number of immobile clustered junctional receptors. An increased AChR insertion rate at the NMJ could saturate the anchoring sites, and a gradient may form as excess AChRs diffuse away. The extrajunctional gradient early after denervation may then result from a similar set of conditions that produce the gradient during development, i.e., a mismatch between junctional $\mathrm{AChR}$ degradation and insertion rates. During development, the $\mathrm{AChR}$ degradation is slowed before AChR synthesis decreases (Reiness and Weinberg, 1981; Steinbach, 1981a), and after denervation, AChR synthesis is stimulated before the degradation rate of the junctional receptors has yet fully accelerated (compare time scale used by Almon and Appel, 1976, and Miledi and Potter, 1971, with that in Levitt and Salpeter, 1981).

These are at present merely conjectures. However, selective insertion of AChR has been demonstrated in regions of nervemuscle contacts in vitro (Role et al., 1985) and is likely to occur 
in vivo due to the higher mRNA present in the endplate band (Merlie and Sanes, 1985). Our results emphasize that a mechanism must exist that maintains and sets an upper limit to the AChR site density at the junction even during periods of altered synthesis and degradation. Detailed information on the junctional $\mathrm{AChR}$ insertion rate and perijunctional diffusion rate, as well as on the activation and depression of individual muscle nuclei, will be necessary to finally clarify the mechanism involved.

\section{References}

Albuquerque, E. X., and R. J. McIsaac (1970) Fast and slow mammalian muscles after denervation. Exp. Neurol. 26: 183-202.

Almon, R. R., and S. H. Appel (1976) Cholinergic sites in skeletal muscle. I. Denervation effects. Biochemistry 15: 3662-3667.

Bader, D. (1981) Density and distribution of $\alpha$-bungarotoxin-binding sites in postsynaptic structures of regenerated rat skeletal muscle. J. Cell Biol. 88: 338-345.

Bevan, S., and J. H. Steinbach (1977) The distribution of $\alpha$-bungarotoxin binding sites on mammalian skeletal muscle developing in vivo. J. Physiol. (Lond.) 267: 195-215.

Burden, S. J. (1977) Development of the neuromuscular junction in the chick embryo: The number, distribution and stability of acetylcholine receptors. Dev. Biol. 57: 317-329.

Chang, C. C., S. Chuang, and M. C. Huang (1975) Effects of chronic treatment with various neuromuscular blocking agents on the number and distribution of acetylcholine receptors in rat diaphragm. J. Physiol. (Lond.) 250: 161-173.

Evans, A. P., W. G. Dail, D. Dammrose, and C. Palmer (1976) Scanning electron microscopy of cell surfaces following removal of extracellular material. Anat. Rec. 185: 433-446.

Fambrough, D. M. (1970) Acetylcholine sensitivity of muscle fiber membranes: Mechanism of regulation by motoneurones. Science 168: 372-373.

Fambrough, D. M. (1974) Acetylcholine receptor: Revised estimates of extrajunctional receptor density in denervated rat diaphragm. J. Gen. Physiol. 64: 468-472.

Fambrough, D. M. (1979) Control of acetylcholine receptors in skeletal muscle. Phys. Rev. 59: 165-227.

Fertuck, H. C., and M. M. Salpeter (1974) Localization of acetylcholine receptors by ${ }^{125}$ I-labelled bungarotoxin at mouse motor endplates. Proc. Natl. Acad. Sci. USA 71: 1376-1378.

Fertuck, H. C., and M. M. Salpeter (1976) Quantitation of junctional acetylcholine receptors by electron microscope autoradiography by ${ }^{125} \mathrm{I}-\alpha$-bungarotoxin binding at mouse neuromuscular junctions. $\mathrm{J}$. Cell Biol. 69: 144-158.

Fertuck, H. C., W. Woodward, and M. M. Salpeter (1975) In vivo recovery of muscle contraction after $\alpha$-bungarotoxin binding. J. Cell Biol. 66: 209-213.

Frank, E., K. Gautvik, and II. Sommerschild (1975) Cholinergic receptors and denervated mammalian motor endplates. Acta Physiol. Scand. 95: 66-75

Goldman, D., J. Boulter, S. Heinemann, and J. Patrick (1985) Muscle denervation increases the level of two mRNA's coding for the acetylcholine receptor $\alpha$-subunit. J. Neurosci. 5: 2553-2558.

Hartzell, H. C., and D. M. Fambrough (1972) Acetylcholine receptors distribution and extrajunctional density in rat diaphragm after denervation correlated with acetylcholine sensitivity. J. Gen. Physiol. 60: 248-262.

Karnovsky, M. J. (1965) A formaldehyde-glutaraldehyde fixative of high osmolarity for use in electron microscopy. J. Cell Biol. 27: 137A.

Karnovsky, M. J., and L. Roots (1964) A "direct-coloring" thiocholine method for cholinesterase. J. Histochem. Cytochem. 12: 219-221.

Kuffler, S. W., and D. Yoshikami (1975) The distribution of ACh sensitivity at the postsynaptic membrane of vertebrate skeletal twitch muscles: Iontophoretic mapping in the micron range. J. Physiol. (Lond.) 244: 703-730.

Labovitz, S. S., N. Robbins, and M. A. Fahim (1984) Endplate topography of denervated and disused rat neuromuscular junctions: Comparison by scanning and light microscopy. Neuroscience 11:963971.

Land, B. R., E. E. Salpeter, and M. M. Salpeter (1980) Acetylcholine receptor site density affects the rising phase of miniature endplate currents. Proc. Natl. Acad. Sci. USA 77: 3736-3740.
Lee, C. Y., S. L. Chang, S. T. Kau, and S. H. Luh (1972) Chromatographic separation of the venom of Bungarus multicinctus and characterization of its components. J. Chromatogr. 72: 71-82.

Levitt, T. A., and M. M. Salpeter (1981) Denervated endplates have a dual population of junctional acetylcholine receptors. Nature 291 : 239-241.

Loring, R., and M. M. Salpeter (1978) ${ }^{125} \mathrm{I}-\alpha$-bungarotoxin binding to denervated muscle: A survey study using light and EM autoradiography. Soc. Neurosci. Abstr. 4: 604.

Loring, R., and M. M. Salpeter (1980) Denervation increases turnover rate of junctional acetylcholine receptors. Proc. Natl. Acad. Sci. USA 77: 2293-2297.

Loring, R. H., S. W. Jones, J. Matthews-Bellinger, and M. M. Salpeter (1982) ${ }^{125}$ I- $\alpha$-bungarotoxin. Effects of radiodecomposition. J. Biol. Chem. 257: 1418-1423.

Matthews-Bellinger, J., and M. Salpeter (1978) Distribution of acetylcholine receptors at frog neuromuscular junctions with a discussion of some physiological implications. J. Physiol. (Lond.) 279: 197-213.

Matthews-Bellinger, J. A., and M. M. Salpeter (1983) Fine structural distribution of acetylcholine receptors at developing mouse neuromuscular junctions. J. Neurosci. 3: 644-657.

McLean, I. W., and P. K. Nakane (1974) Periodate-lysine paraformaldehyde fixation, a new fixative for immunoelectron microscopy. J. Histochem. Cytochem. 22: 1077-1084.

Merlie, J. P., and J. R. Sanes (1985) Concentration of acetylcholine receptor mRNA in synaptic regions of adult muscle fibres. Nature 317: 66-68.

Merlie, J. P., K. E. Isenberg, S. D. Russell, and J. R. Sanes (1984) Denervation supersensitivity in skeletal muscle: Analysis with a cloned cDNA probe. J. Cell Biol. 99: 332-335.

Miledi, R., and L. T. Potter (1971) The acetylcholine receptors in muscle fibres. Nature 233: 599-603.

Morrison, M., and G. S. Bayse (1970) Catalysis of iodination by lactoperoxidase. Biochemistry 9: 2995-3000.

Olek, A. J., and N. Robbins (1981) A nerve stump dependent appearance of junctional and perijunctional receptors in organ culture. Neuroscience $6: 1771-1782$

Olek, A. J., and N. Robbins (1983) Properties of junctional acetylcholine receptors that appear rapidly after denervation. Neuroscience 9: 225-233.

Olek, A., S. Younkin, R. Slugg, M. Konieczkowski, and N. Robbins (1981) A transient increase in junctional acetylcholine receptors after denervation. Brain Res. 214: 429-432.

Pestronk, A., D. Drachman, and J. Griffin (1976a) Effect of muscle disuse on acetylcholine receptors. Nature 260: 352-353.

Pestronk, A., D. Drachman, and J. Griffin (1976b) Effects of botulinum toxin on trophic regulation of acetylcholine receptors. Nature 264 . $787-789$

Porter, C. W., and E. A. Barnard (1975) Distribution and density of cholinergic receptors at the motor endplates of a denervated mouse muscle. Exp. Neurol. 48: 542-550.

Reiness, C. G., and C. B. Weinberg (1981) Metabolic stabilization of acetylcholine receptors at newly formed neuromuscular junctions in the rat. Dev. Biol. 84: 247-254.

Role, L. W., V. Matossian, R. J. O'Brien, and G. D. Fischbach (1985) On the mechanism of acetylcholine receptor accumulation at newly formed synapses on chick myotubes. J. Neurosci. 5: 2197-2204.

Salpeter, M. M. (1981) High resolution autoradiography. In Techniques in the Life Sciences, Techniques in Cellular Physiology, Part I, Vol. 1, P. F. Baker, ed., pp. 1-45, Elsevier-North Holland, Dublin.

Salpeter, M. M., and L. Bachmann (1964) Autoradiography with the electron microscope, a procedure for improving resolution, sensitivity, and contrast. J. Cell Biol. 22: 469-477.

Salpeter, M. M., and L. Bachmann (1972) Autoradiography. In Principles and Techniques of Electron Microscopy, Biological Applications, Vol. 2, M. A. Hayat, ed., pp. 221-278, Van Nostrand Reinhold, New York.

Salpeter, M. M., and R. Harris (1983) Distribution and turnover rate of acetylcholine receptors throughout the junctional folds at a vertebrate neuromuscular junction. J. Cell Biol. 96: 1781-1785.

Salpeter, M. M., and R. H. Loring (1985) Nicotinic acetylcholine receptors in vertebrate muscle: Properties, distribution and neural control. Prog. Neurobiol. 25: 297-325.

Salpeter, M. M., H. Plattner, and A. W. Rogers (1972) Quantitative assay of esterases in end plates of mouse diaphragm by electron microscope autoradiography. J. Histochem. Cytochem. 20: 1059-1068. 
Salpeter, M. M., H. C. Fertuck, and E. E. Salpeter (1977) Resolution in electron microscope autoradiography. III. Iodine-125, the effect of heavy metal staining, and a reassessment of critical parameters. J. Cell Biol. 72: 163-173.

Salpeter, M. M., C. D. Smith, and J. A. Matthews-Bellinger (1984) Acetylcholine receptor at neuromuscular junctions by EM autoradiography using mask analysis and linear sources. J. Electron Microsc. Tech. 1 : 63-81.
Steinbach, J. H. (1981a) Developmental changes in acetylcholine receptor aggregates at rat skeletal neuromuscular junctions. Dev. Biol 84: 267-276.

Steinbach, J. H. (1981b) Neuromuscular junctions and $\alpha$-bungarotoxin-binding sites in denervated and contralateral cat skeletal muscles. J. Physiol. (Lond.) 313: 513-528.

Tower, S. S. (1939) Reaction of muscle to denervation. Phys. Rev. 19: 1-48. 